\title{
PENINGKATAN KECERDASAN KINESTETIK MENGGUNAKAN MODIFIKASI PERMAINAN PADA LESSON STUDY DI SDMOH HATTA MALANG
}

\author{
Bustanol Arifin, Frendy Aru Fantiro, Bahrul Ulum \\ FKIP Universitas Muhammadiyah Malang, Indonesia \\ Email :bustanol_arifin@yahoo.co.id
}

\begin{abstract}
ABSTRAK
Pelaksanaan Lesson Study ini memiliki tujuan yaitu meningkatkan kecerdasan kinestetik menggunakan modifikasi permainan pada kelas 4 di SD Moh. Hatta Malang. Penelitian ini merupakan penelitian deskriptif dengan mengimplementasikan Lesson Study. Adapun subyek penelitian adalah peserta didik kelas 4 di SD Moh. Hatta Malang Pengimplementasian Lesson Study ini dilakukan dalam 4 kali putaran. Tahapan pelaksanaan LS terdiri dari 3 tahapan yaitu: (1) tahap perencanaan (plan), (2) Tahap pelaksanaan (do), serta (3) tahap refleksi (see). Kecerdasan Kinestetik siswa kelas 4 SDN Moh Hatta. Data rata-rata nilai siswa pada matapelajaran PJOK pada siklus I 72,5; siklus II 77,13, siklus III 78,5 dan siklus IV 81,7. Peningkatan dari siklus I ke siklus II 4,63, siklus II ke siklus III 1,37 dan siklus III ke IV 3,25. Lesson Study menyebabkan siswa bersemangat, dalam melakukan kegiatan pembelajaran dan merasa senang sehingga hasil kemampuan gerak kinestetik paserta didik dari siklus I ke siklus IV meningkat.
\end{abstract}

Kata Kunci: Kecerdasan Kinestetik, Modifikasi Permainan, Sekolah Dasar

\begin{abstract}
The implementation of this lesson study has the aim of improving kinesthetic intelligence by using game modification in grade 4 in Moh. Hatta elementary school. This research is a descriptive research by implementing lesson study. The subjects of the research were 4th grade students in Moh. Hatta elementary school.The implementation of this lesson study was conducted in 4 cycles. The stages of LS implementation were consisted of 3 stages: (1) planning stage, (2) Implementation stage (do), and (3) stage of reflection (see). Kinesthetic Intelligence of grade 4 students in Moh Hatta Primary School has the average data on student score of Physical Education learning in cycle I with 72,5 points, cycle II with 77.13 points, cycle III with 78.5 points, and cycle IV with 81,7 points. The points is increasing from cycle I to cycle II by 4.63 , cycle II to cycle III by 1.37 and cycle III to IV by 3,25 . Lesson study causes the students to be excited, in doing the learning activities and feel happy; resulted in the result of kinesthetic ability of the students from cycle I to cycle IV increased.
\end{abstract}

Keywords: Kinesthetic Intelligence, Game Modification, Primary School

\section{PENDAHULUAN}

Penyelenggaraan

pendidikan sebagaimana yang diamanatkan dalam Undang-undang Nomor 20 Tahun 2003 tentang Sistem Pendidikan Nasional diharapkan dapat mewujudkan proses berkembangnya kualitas pribadi siswa sebagai generasi penerus bangsa di masa depan, hal ini diyakini akan menjadi faktor dominan bagi tumbuh kembangnya bangsa dan negara Indonesia sepanjang zaman. Memperhatikan UU tersebut, maka dunia pendidikan menjadi salah satu faktor penentu untuk mencetak generasi berkualitas di masa yang akan datang.

Pada pelaksanaan pendidikan di dalam negeri, secara umum pengaruh arus globalisasi sangat menentukan bentuk permainan anak yang beralih dari permainan menggunakan kemampuan fisik anak menuju permainan berbasis 
teknologi seperti gadget. Di sisi lain, usia anak SD kelas 4 merupakan usia emas di mana anak memiliki sensitivitas yang tinggi terhadap penerimaan segala pengaruh perkembangan, hal ini disebabkan karena kepekaan yang dimiliki anak akan lebih berkembang optimal jika diberikan pada masa ini. Aspek perkembangan yang dapat distimulasi pada anak SD kelas 4 yaitu perkembangan kognitif, bahasa, sosial emosional, nilai moral, agama dan fisik motorik.

Pada masa anak SD kelas 4 kondisi fisik anak sangat tepat untuk diberikan stimulus karena kondisi fisik anak masih kuat dan anak mudah menerima ransangan yang diberikan. Pemberian stimulus terhadap kondisi fisik merupakan awal untuk anak berkembang dan tumbuh dengan baik dan optimal. Pemberian stimulus fisik pada anak akan meningkatkan otot-otot besar pada anak. Perkembangan fisik anak secara khusus berkaitan dengan multiple intelegence dan perkembangan fisik itu sendiri termasuk dalam multiple intelegence yang ada yaitu kecerdasan kinestetik. Kecerdasan kinestetik menurut Armstrong (Musfiroh, 2008:6.3) adalah kemampuan menggunakan seluruh tubuh (fisik) untuk mengekspresikan ide dan perasaan serta keterampilan menggunakan tangan untukmenciptakan atau mengubah sesuatu. Sedangkan menurut Gardner (Grafura, 2011:75) kecerdasan kinestetik merupakan kemampuan menggunakan tubuh secara terampil untuk mengungkapkan ide atau pemikiran dan perasaan, mampu bekerja dengan baik dalam menangani dan memanipulasi objek. Kecerdasan kinestetik mencakup kemampuan menyatakan tubuh dan pikiran dalam sebuah tampilan fisik yang sempurna.
Salah satu upaya untuk meningkatkan kecerdasan kinestetik anak khususnya dalam keterampilan dapat dilakukan dengan kegiatan yang sangat menyenangkan untuk anak berupa permainan.

Permainan yang dapat dilakukan untuk anak SD kelas 4 salah satunya adalah modifikasi permainan, modifikasi permainan merupakan permainan yang sudah ada baik itu permainan tradisional atau permainan modern kemudian di modifikasi menjadi permainan modern yang sesuai dengan kondisi dan tumbuh kembang anak kelas 4 .

Peningkatan kecerdasan kinestetik menggunakan modifikasi permainan pada pembelajaran sangat diperlukan dalam rangka tumbuh kembang anak SD. Hal ini bertujuan untuk mengakomodir tahap perkembangan operational concret pada anak SD, maka perlu menggunakan permainan yang nyata bagi anak. Anak SD kelas 4 diharapkan dapat mengenal permainan yang dapat mengembangkan kecerdasan kinestetiknya ditengah perkembangan permainan berbasis teknologi dimana anak hanya berpikir dan duduk tanpa melakukan aktifitas yang menggerakkan tubuh secara keseluruhan. Modifikasi permainan ini selain meningkatkan kecerdasan kinestetik, dalam aktifitasnya juga terdapat unsur-unsur yang dapat membentuk karakter yang penting bagi anak seperti karakter mandiri, disiplin, tanggung jawab serta karakter-karakter sosial bagi anak.

Pada program Lesson Study ini dirancang dalam empat siklus yang setiap siklus tersusun atas beberapa kegiatan. Lesson Study tersusun atas 3 kegiatan yaitu plan atau perencanaan dimana secara berkelompok guru menyusun perencanaan pembelajaran 
secara bersama, do adalah pelaksanaan pembelajaran dimana salah satu guru akan bertindak sebagai model dan diamati oleh guru-guru yang lain, See adalah refleksi untuk perbaikan proses pembelajaran selanjutnya. Hasil refleksi dapat diperoleh sejumlah pengetahuan baru atau keputusan guna perbaikan dan peningkatan pembelajaran. Pelaksanaan Lesson Study ini memiliki tujuan yaitu meningkatkan kecerdasan kinestetik menggunakan modifikasi permainan pada kelas 4 di SD Moh. Hatta Malang.

\section{METODE}

Penelitian ini merupakan penelitian deskriptifdenganmengimplementasikan Lesson Study. Adapun subyek penelitian adalah peserta didik kelas 4 di SD Moh. Hatta Malang Pengimplementasian Lesson Study ini dilakukan dalam 4 kali putaran. Tahapan pelaksanaan LS terdiri dari 3 tahapan yaitu: (1) tahap perencanaan (plan), (2) Tahap pelaksanaan (do), serta (3) tahap refleksi (see). Hasil yang diharapkan dalam program Lesson Study berbasis sekolah ini adalah peningkatan kecerdasan kinestetik berupa kemampuan fisik motorik anak menggunakan modifikasi permainan, khususnya di kelas $4 \mathrm{SD}$ Moh. Hatta Malang. PLS dilaksanakan dalam empat siklus yang setiap siklus tersusun atas beberapa kegiatan yaitu plan atau perencanaan dimana secara berkelompok guru menyusun perencanaan pembelajaran secara bersama, do adalah pelaksanaan pembelajaran dimana salah satu guru akan bertindak sebagai model dan diamati oleh guru-guru yang lain, See adalah refleksi untuk perbaikan proses pembelajaran selanjutnya. Hasil refleksi dapat diperoleh sejumlah pengetahuan baru atau keputusan guna perbaikan dan peningkatan pembelajaran.

\section{HASIL DAN PEMBAHASAN HASIL \\ Kunjungan untuk melakukan Lesson Study}

Hasil kegiatan kunjungan untuk pengabdian kepada pihak sekolah dilakukan pada tanggal 4 April 2017. Adapun maksud kunjungan, yaitu menyampaikan kegiatan pengabdian berupa LS berkenaan dengan teknis pelaksanaan kegiatan dan kesepakatan tanggal pelaksanan pembuatan Lesson Design untuk LS.

Hasil kunjungan ke pihak sekolah sempat mendiskusikan tentang menanyakan tentang perbedaan PTK dan LS di SD Moh Hatta karena sama-sama memiliki kegiatan yang bersiklus. Penjelasan pelaksana pengabdian terkait perbedaan PTK dan LS adalah sebagai berikut

1. PTK merupakan penelitian yang didasarkan oleh masalah atau penyakit atau yang di temukan pada saat proses pembelajaran di kelas yang di dasarkan pada tiga hal yaitu pertama aktivitas guru (cara mengajar guru) pada materi atau pembahasan tertentu, kedua aktivitas siswa (kegiatan siswa yang didasarkan cara mengajar guru), ketiga hasil belajar siswa akibat cara mengajar guru yang didasarkan pada kriteria ketuntasan minimal secara klasikal yang ditentukan oleh sekolah pada mata pelajaran tertentu. Permasalahan tersebut harus diberi dianalisis kemudian dirumuskan sebuah solusi/ obat.

2. Lesson Study merupakan penjamin mutu pembelajaran artinya bahwa LS digunakan untuk menciptakan kegiatan pembelajaran yang berkualitas. 
Pendampingan plan pembuatan RPP

Pelaksanaan kunjungan awal pra pelaksanaan LS telah dilaksanakan, kemudian diterapkan dengan kegiatan menyusun perangkat pembelajaran oleh guru PJOK yang berupa RPP berbasis LS. LS dilakukan 4 siklus dimana pada proses plan dilakukan 2 siklus dilakukan di kantor PGSD UMM pada tanggal 18 dan 19 April 2017 sedangkan pelaksanaan plan 2 siklus berikutnya dilakukan di SD Moh Hatta pada tanggal 25 dan 26 April 2017. Pelaksnaan kegiatan plan yakni penyusunan perangkat pembelajaran bersama guru PJOK SD Moh Hatta dengan didampingi 3 orang tim pengabdian, tim pengabdian mendampingi guru secara maksimal. 3 orang tim pengabdi secara bersama melakukan pendampingan dalam penentuan plan dan bergantian menjadi notulen dan moderator. Pendampingan pembuatan plan di SD Moh Hatta dihadri oleh guru PJOK yang sekaligus menjadi guru model yaitu: Bpk Antariksa Genta, S. Pd yang merupakan guru PJOK satu-satunya di SD Moh Hatta. Pembuatan plan berupa RPP tetntang modifikasi permainan pada pembelajaran tematik kurikulum 2013 revisi 2016 dibuat untuk kelas 4 SD dengan alasan sebagai berikut:

1. Pelaksanaan kurikulum 2013 revisi 2016 masih dilaksanakan di kelas 1 dan kelas 4

2. Pelaksanaan modifikasi permainan baru dilaksanakan pada kelas tinggi yakni kelas 4,5,6

3. Berdasarkan alasan ke 1 dan 2 disimpulkan pelaksanaan modifikasi permainan pada pembelajaran tematik kurikulum 2013 revisi 2016 dilaksanakan untuk kelas 4 .

Hasil dari pendampingan ini berupa RPP untuk 4 siklus LS. Fokus pembelajaran untuk siswa, yaitu modifikasipermainan padapembelajaran tematik kurikulum 2013 revisi 2016. Namun, tim pelaksana pengabdian memberikan kesempatan terbuka untuk melaksanakan pendampingan jika dibutuhkan, dengan memanfaatkan kecanggihan media IT melalui telepon, sms, email dan media sosial (facebook, line, whatsapp, telegram). Bukti pelaksanaan pendampingan disajikan pada gambar dibawah ini.

Saat pembuatan RPP guru model menentukan materi yang sesuai dengan kalender akademik yang dibuat oleh sekolah. Pada saat pelaksanaan plan kegiatan pembelajaran dibuat memperhatikan karakteristik siswa. Karakteristik siswa didasarkan pada penjelasan guru model yang secara langsung memperhatikan karater siswanya saat proses pembelajaran yang telah dilaksanakan sebelumnya. Harapannya siswa ada inovasi dalam pembelajaran yang dapat meningkatkan antusias siswa dalam belajar sehingga pembelajaran tidak terkesan monoton di satu sisi harapan lain juga agar guru dapat mencontoh dan melakukan kegitan pembelajaran yang lebih baik dalam rangka menjamin mutu pembelajaran. Pada kegiatan plan pembuatan RPP di susun berdasarkan materi dan KD yang cocok dengan pelaksanaan modifikasi permainan,

\section{Pelaksanaan (Do) LS modifikasi permainan di kelas 4 SD. \\ RPP (Lesson Design) dan materi} (Chapter Design) pembelajaran LS telah disusun, maka guru-model siap untuk melakukan pembelajaran di kelas 4 SD Moh Hatta dengan 1 guru model dan observer dari tim pendamping 
dosen PGSD UMM saat pelaksanan pembelajaran. Praktik dalam bentuk pembelajaran berbasis LS dilakukan masing-masing 4 kali pertemuan (4 siklus) dengan jadwal pelaksanaan sebagai berikut

\section{Tabel 1 Jadwal Pelaksanaan (Do) Pembelajaran}

\begin{tabular}{cccc}
\hline No & Siklus & Tempat & Tanggal Pelaksanaan \\
\hline 1 & Siklus 1 & SD MOH HATTA & 5 april 2017 \\
\hline 2 & Siklus 2 & SD MOH HATTA & 24 mei 2017 \\
\hline 3 & Siklus 3 & SD MOH HATTA & 23 agustus 2017 \\
\hline 4 & Siklus 4 & SD MOH HATTA & 6 september 2017 \\
\hline
\end{tabular}

Guru model melakukan apersepsi tentang materi yang akan dilaksanakan. Pembelajaran tentang modifikasi permainan menggunakan alat berupa, media yang digunakan: bola, tiang modifikasi, stopwatch dan pluit Siswa melakukan pemanasan terlebih dahulu kemudian mlakukan permainan zig zag run yang bertujuan mengembangkan keterampilan lokomotor, non lokomotor dan manipulatif kegiatan disajikan pada gambar dibawah ini

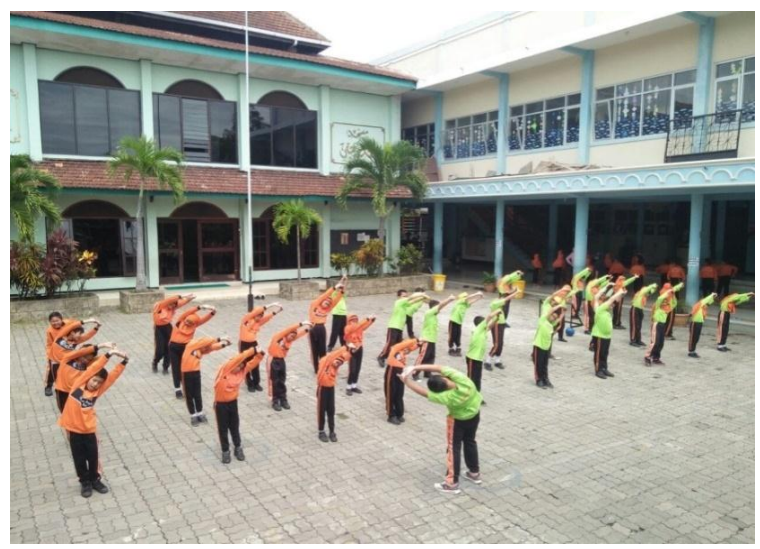

Gambar 1. Pemanasan Dilakukan Siswa Berdasarkan Instruksi Guru Model

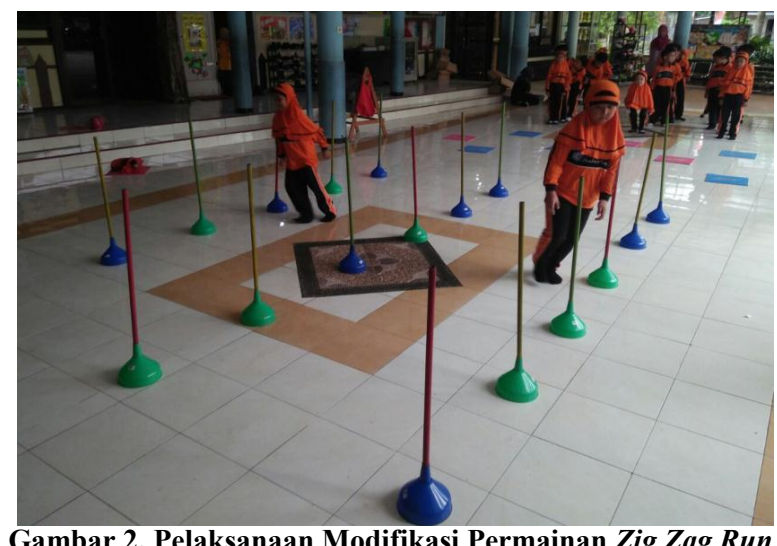

Bustanol Arifin, Frendy Aru Fantiro, Bahrul Ulum, Peningkatan Kecerdasan Kinestetik Menggunakan Modifikasi Permainan Pada Lesson Study di SD Moh. Hatta Malang 


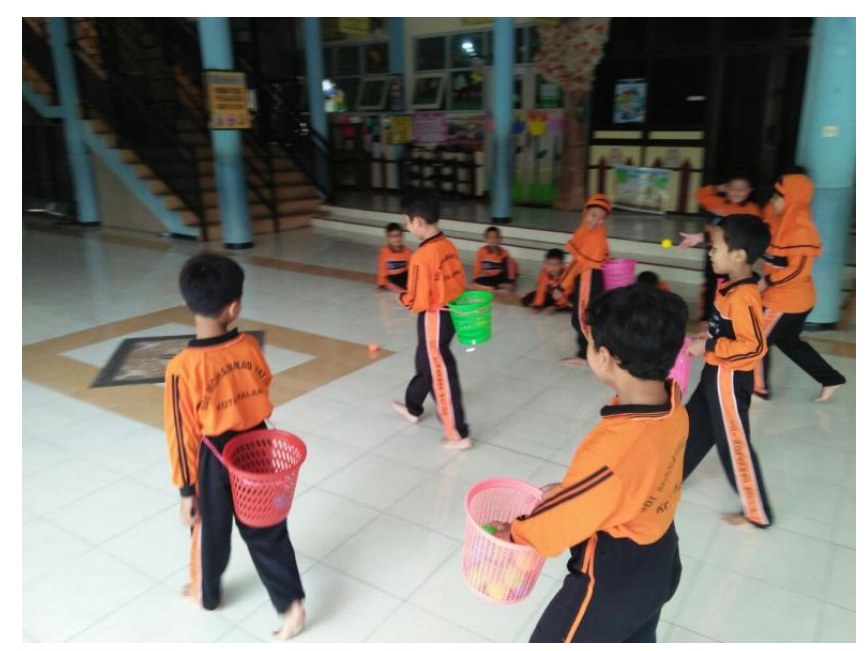

Gambar 3. Permainan Lempar Bola Keranjang

Setelah pelaksanaan siswa diajak untukmelakukan refleksidankesimpulan dari kegiatan yang dilakukan. Hal ini dilakukan dalam rangka agar siswa mendapatkan pembelajaran dari kegiatan pembelajaran yang dilakukan. Kemudian guru membuat sebuah kesimpulan dari pelaksanaan modifikasi permainan yang dilaksanakan.

\section{Pelaksanaan Refleksi (See) pembelajaran modifikasi permainan di kelas 4 SD.}

Guru model telah melakukan pembelajaran. Tahap selanjutnya dilakukan refleksi kegiatan do yang dilaksanakan untuk LS. Saat refleksi akan didiskusikan apa yang bisa diungkap dari prose pembelajaran yang dilakukan siswa. Pertama, guru model mengungkapkan perasaan saat pelaksanaan pembelajaran di kelas. Observer mengemukakan apa yang diamati saat siswa melaksanakan .pembelajaran PJOK tentang modifikasi permainan pada kurikum 2013 revisi 2016 Data Peningkatan Kebugaran Jasmani Siswa pada Kegiatan Pelaksanaan Modifikasi Permainan

Data nilai siswa didapatkan dari analisis pelaksanaan modifikasi permainan siswa. Skor nilai didapatkan dari rata-rata pelaksanaan tiap siklus.

\section{Tabel 1. Data Rata-Rata Pelaksanaan Modifikasi Permainan Tiap Siklus}

\begin{tabular}{cccccc}
\hline No & Parameter & Siklus I & Siklus II & Siklus III & Siklus IV \\
\hline 1 & Kelincahan & 75 & 80 & 80 & 82 \\
\hline 2 & Kekompakan & 75 & 80 & 82 & 85 \\
\hline 3 & Ketepatan & 70 & 75.5 & 79 & 80 \\
\hline 4 & Kecepatan & 70 & 73 & 77 & 80 \\
\hline & Rata-rata & 72.5 & 77.15 & 78.5 & 81,7 \\
\hline
\end{tabular}

Data rata-rata nilai siswa pada mata pelajaran PJOK berkaitan tentang modifikasi permainan menggunakan empat parameter yaitu 1) Kelincahan adalah kemampuan anak dalam bergerak cepat dan tepat, 2) Kekompakan adalah kemampuan anak dalam saling mendukung, 3) Ketepatan adalah kemampuan anak mengarahkan gerak pada tujuan yang akan dicapai 
dan 4) Kecepatan adalah kemampuan berpindah dari satu tempat ke tempat lain menggunakan hitungan waktu.

Dari hasil rata-rata pelaksanaan modifikasi permainan dapat diketehui bahwa pada siklus I 72,5; siklus II 77,13 , siklus III 78,5 dan siklus IV 81,7 Peningkatan dari siklus I ke siklus II 4,63; siklus II ke siklus III 1,37 dan siklus III ke IV 3,25. Berdasarkan hasil tersebut maka pelaksanaan Lesson Study menyebabkan siswa antusias dan merasa senang sehingga hasil belajar paserta didik dari siklus I ke siklus IV meningkat.

\section{HASIL DAN PEMBAHASAN}

Temuan saat kunjungan pra pelaksanaan Lesson Study, yaitu pihak sekolah SD Moh Hatta Malang sangat senang bisa berkolaborasi dengan PGSD UMM dalam pelaksanaan upaya penjaminan mutu pembelajaran. Guru yang terlobat dalam pendampingan ternyata bersemangat untuk belajar dalam meningkatkan kompetensi dan profesionalisme mutu pembelajaran berbasis Lesson Study. Hal ini sesuai dengan pendapat Hendayana (2007) yang menyatakan model pembinaan profesi pendidik melalui pengkajian pembelajaran secara kolaboratif dan berkelanjutan berdasarkan prinsipprinsip kolegalitas dan mutual learning untuk membangun komunitas belajar.

Temuan saat pendampingan pembuatan perencanaan perangkat pembelajaran Praktik PJOK tentang modifikasi permainan di kelas 4 SD Moh Hatta untuk do di kelas, yaitu guru mata pelajaran PJOK mempunyai semangat yang tinggi untuk belajar. Hal ini ditunjukkan dengan saat plan dihadiri oleh guru PJOK sebagai guru model. Saat kegiatan diskusi plan, guru model saling memberikan pendapat, bekerjasama untuk mewujudkan perencanaan tersebut. Pada plan ini tercipta suasan intelektual yang nyaman sehingga tercipta komunitas belajar sehingga tidak ada guru yang merasa dikritik. Hal ini sesuai pendapat Lutfi (2007), yang menyatakan bahwa pada saat plan LS, mendiskusikan bagaimana membelajarkan siswa yang dibangun dari komunitas belajar melalui sharing diantara guru segingga menekankan pada prinsip kolegialitas dan mutual learning. Konsep LS yang dilaksanakan di Jepang digunakan untuk pembinaan profesi guru secara berkelanjutan.

Penerapan Pembelajaran Praktik dengan menggunakan modifikasi permainan pada pembelajarn tematik kurikulum 2013 revisi 2016 pada kelas 4 SD berdasarkan observasi bahwa pelaksanaan pembelajaran berpusat pada siswa. Siswa sangat antusias melaksanakan kegiatan pembelajaran dengan guru sebagai fasilitator. Siswa dengan rasa senang melakukan kegiatan olahraga melalui modifikasi permainan akan meningkatkan keterampilan siswa.

Temuan saat refleksi pelaksaan pembelajaran, guru menyampaikan kesan pada saat pelaksanaan pelaksanaan Lesson Study mulai dari plan, do dan see. Oserver sekaligus tim pendamping saat melakukan refleksi mengomentari dan mengoreksi pelaksanaan pembelajaran saat guru mengajar bukan bagaimana saat siswa belajar. Pada saat RPP dibuat secara kolaboratif antara pendamping dan guru model sehingga merupakan hasil pemikiran bersama. Oleh karena itu, saat refleksi observer atau guru harus mengamati bagaimana siswa belajar

Temuan, data rata-rata peningkatan kecerdasan kinestetik siswa pada mata pelajaran PJOK pada siklus I 72,5; 
siklus II 77,13 dan siklus III 78,5. Siklus IV 81,7 Peningkatan dari siklus I ke siklus II 4,63; siklus II ke siklus III 1,37.Siklus III ke IV 3, 25 Lesson Study menyebabkan siswa antusias dan merasa senang sehingga hasil belajar paserta didik dari siklus I ke siklus III meningkat.

Kontribusi program dalam rangka meningkatkan kualitas pembelajaran di sekolah dan LPTK serta perbaikan mutu guru dan dosen.

- Program ini sangat berkontribusi ke sekolah karena guru saling berkolaborasi, membentuk learning community, pembelajaran yang menyenangkan. Program LS bukan untuk mengkritik guru tetapi mengamati bagaimana siswa belajar.

- Bagi LPTK program ini sebagai program proliferasi LS di sekolah

Kendala yang dihadapi dalam pelaksanaan LS adalah ketika waktu pelaksanaan pendampingan berbenturan dengan beberapa kegiatan sekolah yang telah terjadwal sebelumnya baik kegiatan di dalam sekolah maupun di luar sekolah: sehingga pelaksanaan pendampingan LS di SDN Moh Hatta sempat tertunda dari jadwal yang ditentukan.

Tindak lanjut program yang direncanakan. Deskripsikan secara singkat rencana kegiatan tindak lanjut pada tahun berikutnya Program LS ini berkelanjutan, guru masih perlu pendampingan dalam pelaksnaan LS. Guru perlu dilatih dalam menciptakan pembelajaran yang inovatif dan membuat antusias bagi siswa serta guru perlu didampingi pembuatan artikel ilmiah dari pelaksanaan LS sebagai dokumen kegiatan guru.

\section{SIMPULAN}

Pelaksanaan Lesson Study di SDN Moh Hatta dapat disimpulkan bahwa RPP (lesson design) dan materi pembelajaran LS telah disusun, maka guru-model siap untuk melakukan pembelajaran di kelas 4 SD Moh Hatta dengan guru PJOK sebagai guru model dan observer (dari Dosen PGSD UMM). Saat pelaksanan pembelajaran, LS dilakukan masing-masing 4 kali

Kecerdasan Kinestetik siswa kelas 4 SDN Moh Hatta. Data rata-rata nilai siswa pada matapelajaran PJOK pada siklus I 72,5; siklus II 77,13 dan siklus III 78,5. Siklus IV 81,7 Peningkatan dari siklus I ke siklus II 4,63; siklus II ke siklus III 1,37.Siklus III ke IV 3, 25 Lesson Study menyebabkan siswa bersemangat, dalam melakukan kegiatan pembelajaran dan merasa senang sehingga hasil kemampuan gerak kinestetik paserta didik dari siklus I ke siklus IVmeningkat.

\section{DAFTAR PUSTAKA}

Hendayana, Sumar dkk. 2007. Lesson Study, suatu strategi untuk meningkatkan keprofesionalan pendidik (pengalaman IMSTEPJICA) Bandung:IPI Press

Lutfi, A., (2007a). Lesson Study Sebagai Model Pembinaan Guru Kimia. (Makalah Seminar Nasional Kimia 2007). Surabaya: Jurusan Kimia FMIPA, Unesa.

Musfiroh Tadkiroatun. 2008. Materi Pokok Pengembangan Kecerdasan Majemuk. Jakarta: Universitas Terbuka

Grafura Lubis, dkk. 2011.Permainan Edukatif Untuk Pembelajaran Atraktif. Jakarta: Prestasi Pustaka publisher 
Syamsuri, I. dan Ibrohim. 2008. Lesson study (Studi Pembelajaran). Malang: FMIPA Universitas Negeri Malang.

Wikipedia.2007. Lesson study. Online: http://en.wikipedia.org/wiki/ Lesson_study.
Undang-Undang Republik Indonesia, Nomor: 20 Tahun 2003, tentang, SISDIKNAS (Sistem Pendidikan Nasional), Penerbit Fokusmedia Bandung. 